\title{
RARE AND THREATENED PONDWEED COMMUNITIES IN ANTHROPOGENIC WATER BODIES OF OPOLE SILESIA (SW POLAND)
}

\author{
ARKADIUSZ NOWAK ${ }^{1}$, SYLWIA NOWAK ${ }^{1}$, \\ IZABELA CZERNIAWSKA-KUSZA ${ }^{2}$ \\ ${ }^{1}$ Department of Biosystematics \\ Laboratory of Geobotany and Plant Conservation, University of Opole \\ Oleska 48, 45-052 Opole, Poland \\ 2 Department of Land Cover Protection, University of Opole
}

(Received: May 14, 2006. Accepted: August 16, 2006)

\begin{abstract}
The paper presents results of geobotanic studies conducted in anthropogenic water bodies like excavation ponds, fish culture ponds, other ponds, dam reservoirs, ditches, channels and recreational pools incl. watering places in Opole Silesia and surroundings in the years 2002-2005. The research focused on occurrence of threatened and rare pondweed communities. As the result of the investigations of several dozen of water bodies, 28 localities of rare pondweed communities were documented by 75 phytosociological relevés. Associations of Potametum trichoidis J. et R Tx. in R. Tx. 1965, Potametum praelongi Sauer 1937, P. alpini Br.-B1. 1949, P. acutifolii Segal 1961, P. obtusifolii (Carst. 1954) Segal 1965 and P. perfoliati W. Koch 1926 em. Pass. 1964 were found as well as communities formed by Potamogeton berchtoldii, P. nodosus and P. pusillus.

The study confirms that anthropogenic reservoirs could serve as last refugees for many threatened pondweed communities, which decline or even extinct in their natural habitats. The results indicate that man-made habitats could shift the range limits of threatened species and support their dispersal. The authors conclude that habitats strongly transformed by man are important factors in the natural syntaxonomical diversity protection and should not be omitted in strategies of nature conservation.
\end{abstract}

KEY WORDS: pondweed communities, anthropogenic reservoirs, syntaxonomical diversity, Potamogeton sp., Potamion.

\section{INTRODUCTION}

South-West Poland is an unfavourable area for the development of pondweed communities. There are many data on retreating tendencies of pondweeds and their communities within the region and its surroundings (e.g., Bernacki et al. 2000; Kącki et al. 2003; Nowak et al. 2003; Celiński et al. 1997; Kaplan and Čeřovský 2001; Procházka 2001; Procházka and Husák 2001; Procházka and Rydlo 2001). Opole Silesia located outside the lake districts of Poland is characterized by a scarcity of natural water reservoirs. Some ox-bow lakes with a vegetation cover typical for their eutrophic waters occur only within the valleys of large rivers, like Odra, Nysa Kłodzka, Mała Panew and Stobrawa. However, the lack of broadly distributed natural water bodies is compensated by many artificial reservoirs, built by man for agricultural, flood-control or recreational purposes. They have become an important habitat for many rare and threatened plants and plant communities.

During the last decades, due to water shortages and also economic reasons, large dam reservoirs (e.g. Otmuchow- ski, Nyski, Turawski) as well as fish-pond complexes (e.g. Izbicko-Utrata, Niemodlin, Krogólno) and many other small ponds of local importance have been built in the Opole Silesia. The artificial water bodies are frequently postmining activity remains, like in the case of gravel-, sand- and clay-pits or quarries. The water-aimed reclamation of quarries is considered as the cheapest and also environmental friendly way of land reclamation procedure, of course, if the hydrogeological conditions are favourable. In the last few years the first trial was done to compensate the negative influence of the river regulation and several artificial ponds were dug in the valley where few ox-bow lakes had been covered in.

Creation of artificial water bodies has biogeographical consequences for many aquatic plants and communities. The artificial reservoirs support expansion of water plants to the previously never occupied areas, which is significantly important on the areas with scarcity or even without natural water bodies. The diversity of physical-chemical characteristics of the man-made water ecosystems and their biocoenotic features are also important as they provide 
special habitats for rare plant communities. The majority of the artificial ponds has clear, meso- or moderately eutrophic waters with no or very poor plant cover (very favourable for pioneer vegetation).

As the natural ox-bow lakes in the Opole Silesia region have been destroyed by flood control investments (despite of their legal protection!) the artificial water bodies are substitute habitats and sometimes the only opportunity for the existence of many threatened pondweed communities.

So far, the pondweed communities have never been an object of special geobotanical investigations in the Opole Silesia. The interesting comparative data were published for the neighbouring Upper Silesia by Sendek (1976).

\section{MATERIAL AND METHODS}

Geobotanic studies in the years 2002 to 2005 were carried in the areas of anthropogenic reservoirs in the Opole Silesia and neighbouring regions (Fig. 1). Generally, 28 sites and 75 vegetation plots with rare pondweed occurrence were sampled using phytosociological Braun-Blanquet approach (1964).

The phytosociological relevés were made in 12 types of anthropogenic reservoirs: gravel-pit's waters (14), claypit's waters (12), reservoirs in quarries (12), fish culture ponds (8), sand-pit's waters (6), other ponds (6), canals (5 relevés), drainage ditches (4), dam reservoirs (3), fire emergency ponds (2), recreational ponds, incl. watering places (2) and mid-field pools (1).

The object of the investigation were plant communities built by threatened pondweed species. Threat level was determined according to the local red lists of vascular plants (Bernacki et al. 2000; Kącki et al. 2003; Nowak et al. 2003). Thus, the communities created by Potamogeton acutifolius Link, $P$. alpinus Balb., $P$. berchtoldii Fieber, $P$. nodosus Poir., P. obtusifolius Mert. \& W.D.J. Koch, P. perfoliatus L., $P$. praelongus Wulfen, $P$. pusillus L. and $P$. trichoides Cham. \& Schltdl. were investigated. Communities of $P$. lucens L. and $P$. pectinatus L. were not included, because of their spreading and expansion rate with no visible threat symptoms in any type of habitat. The threat level of pondweed communities was estimated according to $\mathrm{Ce}$ liński et al. (1997). All collected specimens are stored at OPUN. The location with the nearest village or city, short habitat description and the ATPOL square $10 \times 10 \mathrm{~km}$ according to Zając (1978) are presented within the register of the communities.

Relevés were numerically classified using the binary approach (absence or presence of the species) and the cover scale of particular species. The similarity index was calculated using Jaccard's formula for the binary data and Rouzicka's formula for the ratio scale data. Similarity matrixes were grouped according to the method of unweighted

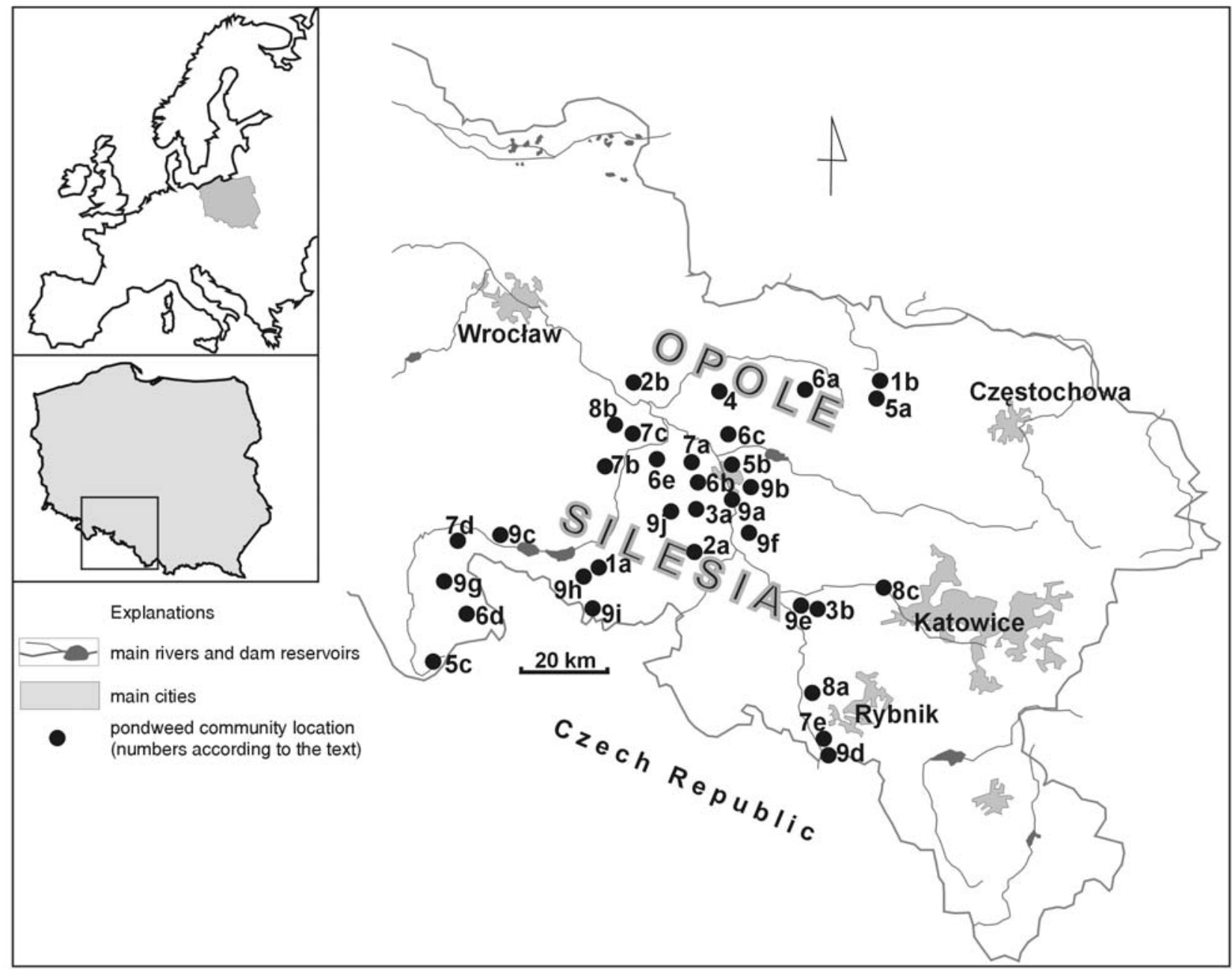

Fig. 1. Distribution of rare and threatened pondweed communities in the Opole Silesia and neighbouring areas. 
pair-group average, i.e., UPGMA (Sneath, Sokal 1973, Figs 2-4).

The species nomenclature follows Mirek et al. (2002). As phenological aspects were considered in the fieldwork, basic investigations were conducted from July to October, in the years 2002 to 2005 . The syntaxonomical classification was done according to Matuszkiewicz (2001), Pott (1995) and Schubert et al. (1995). However, because of the high level of disturbances and instability of the investigated ecosystems, in some cases only communities indicated by the dominant species were distinguished, according to Pott (1995).

To assess the habitat conditions the ecological indicator values were used according to Ellenberg (1974) and the species diversity was calculated using the Shannon-Wiener index, also known as Shannon-Weaver index (Shannon, Wiener 1963). For each community the mean species value, Shannon-Wiener diversity index ( $\left.\mathrm{H}^{\prime}\right)$ and the Ellenberg Indicator values for light (L), temperature (T), continentality $(\mathrm{C})$, moisture $(\mathrm{M})$ and reaction $(\mathrm{R})$ were calculated (Table 1).
The trophic level of an ecosystem is usually evaluated according to the results of the total nitrogen, total phosphorus, chlorophyll a, transparency and biological parameters (Dodds et al. 1998). However, it is generally admitted that phosphorus plays an important role in the development of aquatic plants and, in most cases, is a limiting factor of eutrophication in temperate lakes (Parinet et al. 2004). In order to estimate the status of investigated water bodies, Trophic State Index (TSI) was calculated according to Carlson's equations (Carlson 1977):

$$
T S I=\frac{T S I(T P)+T S I(S D)}{2}
$$

where

TSI $(\mathrm{TP})=10\left[6-\log \left(48 \cdot \mathrm{TP}^{-1}\right) \cdot \log 2^{-1}\right]$

TSI $(\mathrm{SD})=10\left(6-\log S \mathrm{D} \cdot \log 2^{-1}\right)$

$\mathrm{TP}$ - total phosphorus $\left(\mathrm{mg} \cdot \mathrm{m}^{-3}\right), \mathrm{SD}-$ Secchi depth $(\mathrm{m})$.

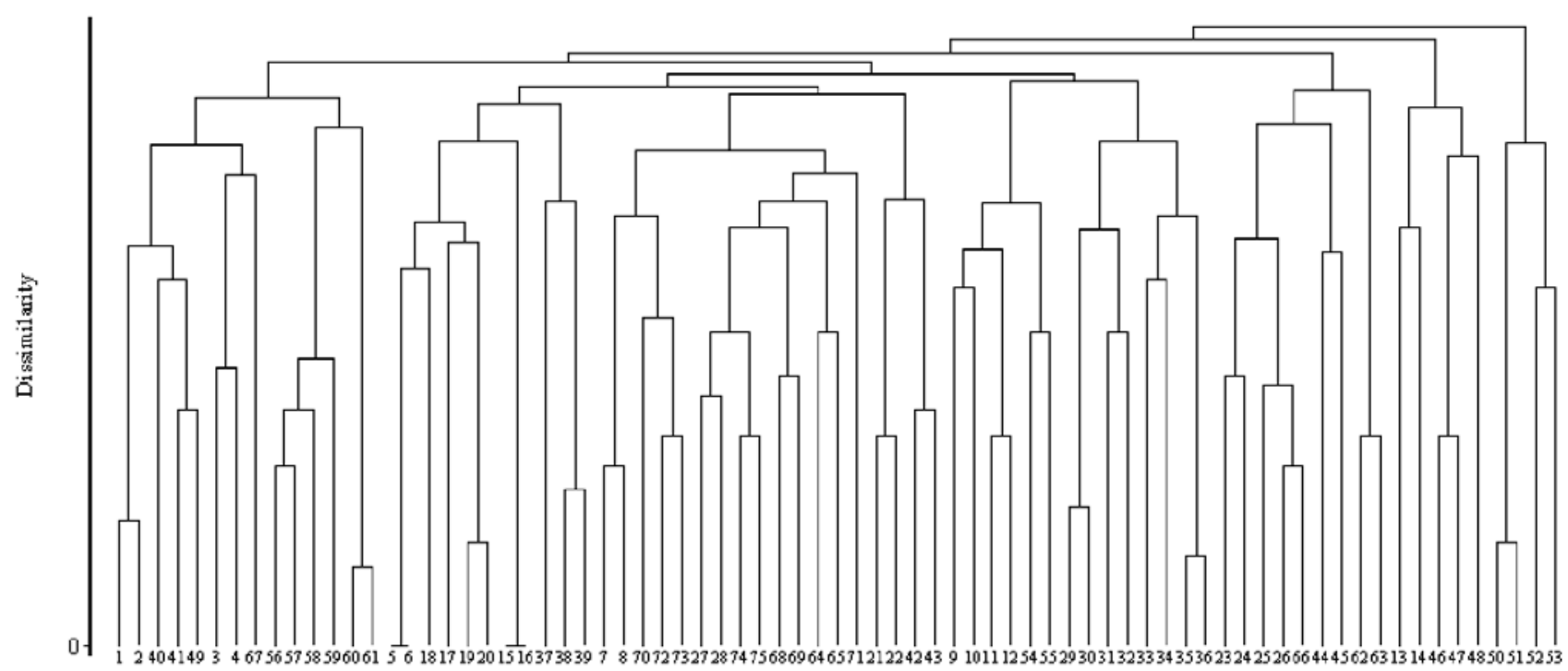

Fig. 2. Dissimilarity dendrogram of the investigated Potamogeton-communities according to Jaccard formula for the binary data (axis X: field record numbers).

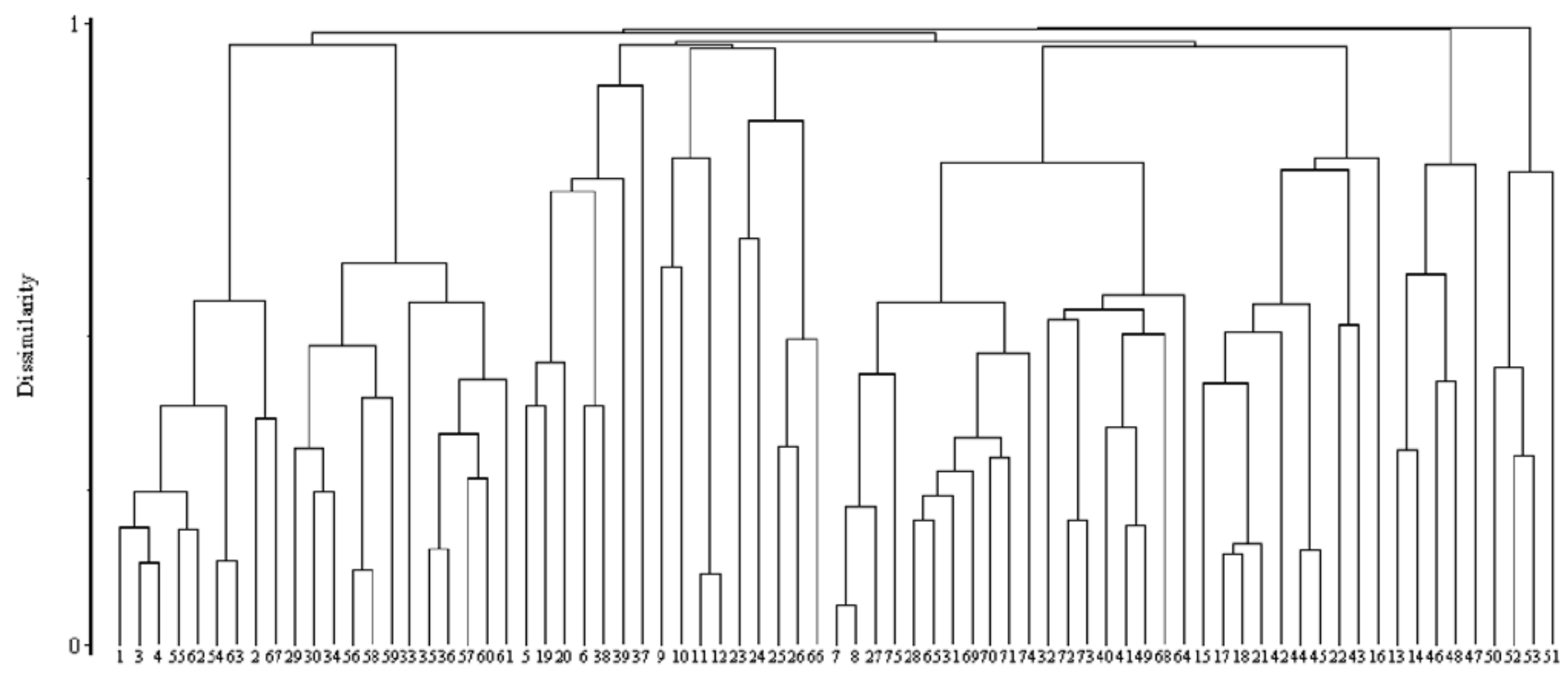

Fig. 3. Dissimilarity dendrogram of the investigated Potamogeton-communities according to Rouzicka formula - for ratio scale data (axis X: field record numbers). 


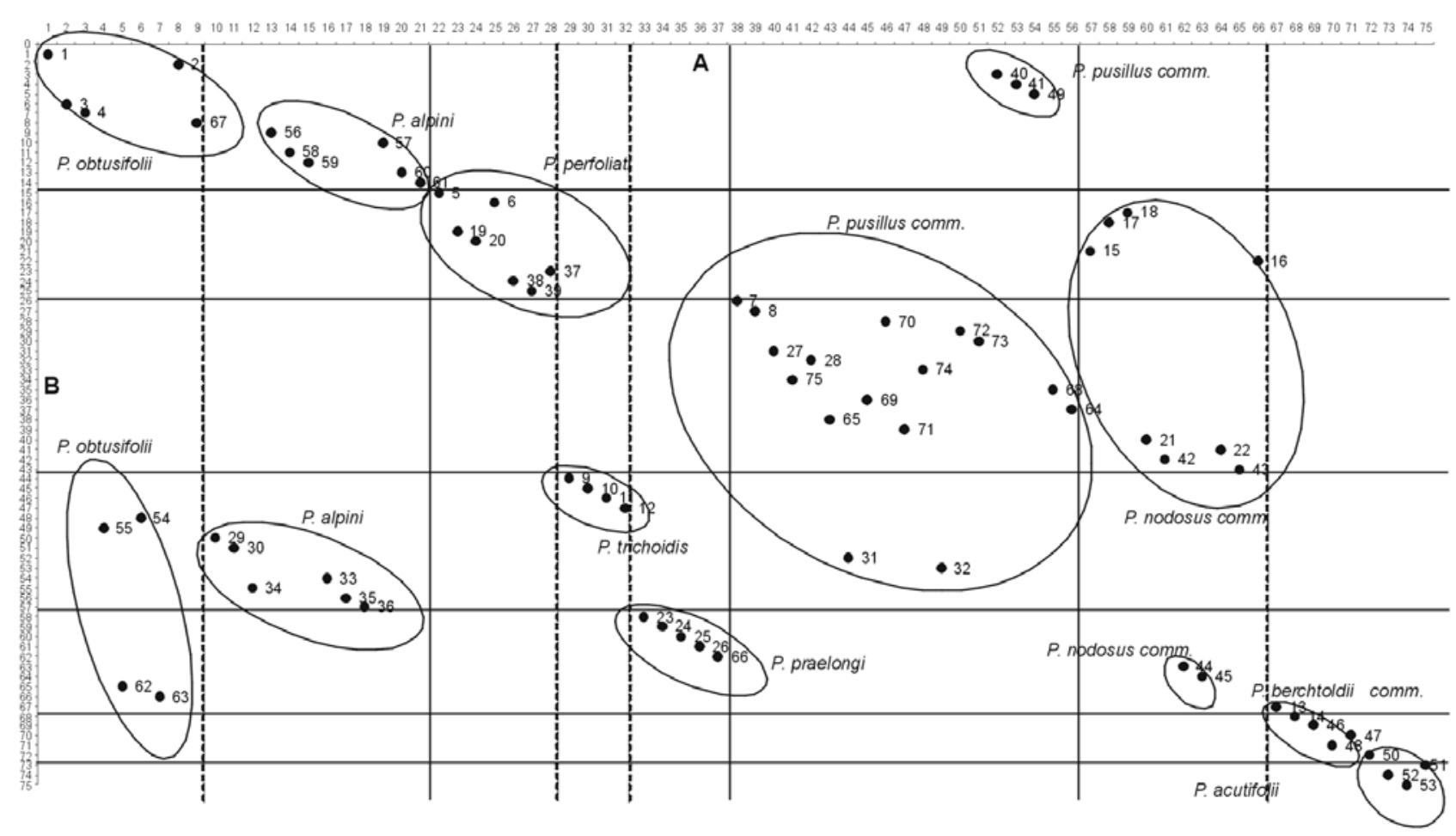

Fig. 4. Dispersion diagram for the relevés done in the patches of different pondweed communities within the area of Opole Silesia. The numbers on diagram follows the relevés numbers in phytosociological tables, i.e., field record numbers. A - qualitative (0; 1); B - quantitative (the Braun-Blanquet quantity scale).

TABLE 1 . The mean values of species richness, diversity and ecological indicators for the researched pondweed communities (see abbreviation in the text).

\begin{tabular}{|c|c|c|c|c|c|c|c|}
\hline Community & Species number & $\mathrm{H}^{\prime}$ & $\mathrm{L}$ & $\mathrm{T}$ & $\mathrm{C}$ & M & $\mathrm{R}$ \\
\hline Potametum trichoidis & 3.75 & 1.07 & 6.76 & 6.10 & 5.00 & 11.30 & 6.66 \\
\hline Potametum praelongi & 5.60 & 1.02 & 6.72 & 5.45 & 4.34 & 11.50 & 7.43 \\
\hline Potametum acutifolii & 5.25 & 1.03 & 7.19 & 5.87 & 3.45 & 10.35 & 5.73 \\
\hline Potamogeton berchtoldii comm. & 4.60 & 0.70 & 6.90 & 5.92 & 4.20 & 10.15 & 6.88 \\
\hline Potametum obtusifolii & 5.55 & 0.65 & 7.04 & 5.71 & 3.79 & 10.30 & 6.79 \\
\hline Potametum perfoliati & 5.28 & 1.21 & 6.18 & 5.83 & 4.80 & 11.20 & 7.37 \\
\hline Potamogeton pusillus comm. & 5.57 & 1.04 & 6.55 & 5.51 & 4.73 & 10.85 & 7.02 \\
\hline
\end{tabular}

The TSI values, constructed on a scale of 0 to 100 , indicate the trophic level of ecosystems from oligotrophic $(<40)$ to eutrophic $(60-100)$.

\section{RESULTS}

Altogether several dozen artificial water bodies were investigated, mainly located in different types of excavations, but also ponds, dammed reservoirs and recreational waters. During the studies 75 phytosociological relevés were done (Tables 2, 3). In researched community patches the species richness varied between 2 and 12 taxa, with the mean value of 5.56. The mean value of the species diversity was 0.97 (from 0.06 to 1.93 ). The habitat characteristics, obtained by summing up the indicator values of all species present in the sampled community patch, were as follows: for light -6.66 (5.67-7.6), for temperature 5.64 (5-6.5), for continentality -4.38 (3-5.5), for humidity -10.8 (8.5-12) and for reaction - 6.91 (5.25-8.33).
Nine communities of threatened pondweeds were found in 28 artificial water ecosystems.

\section{Potametum trichoidis J. et R Tx. in R. Tx. 1965}

Loose aggregations of Potamogeton trichoides were found to the north-west from Wierzbięcice (in the clay-pit and small earthworks; CF21 - 1a locality, see Fig. 1), as well as in the clay-pit in Wysoka-Dąbrowa (CE79 - 1b). In both cases the association occupied small areas and was pushed and overgrown by more dense and dynamic assemblages of $P$. crispus and $P$. pusillus (Table 3, rel. no 14-17). Although the diagnostic species, $P$.trichoides, was found in clay-pits near Leśnica (Schube 1905), the Potametum trichoidis association has not been reported from anthropogenic reservoirs in Opole Silesia later on. It is supposed that this association has more anthropogenic stands, but because of its inconspicuousness, especially when occurs with P. pusillus (Pott 1995), it can be easily overlooked. 


\begin{tabular}{lccccc} 
Location & $\begin{array}{c}\text { Temp. } \\
{\left[{ }^{\circ} \mathrm{C}\right]}\end{array}$ & $\mathrm{pH}$ & $\begin{array}{c}\text { Trans- } \\
\text { parency } \\
{[\mathrm{cm}]}\end{array}$ & $\begin{array}{c}\text { Total P } \\
{\left[\mathrm{mg} / \mathrm{dm}^{3}\right]}\end{array}$ & TSI \\
\hline Wysoka-Dąbrowa & 19.2 & 7.2 & 60 & 0.508 & 64
\end{tabular}

\section{Potametum praelongi (Milian) Sauer 1937}

The association was found in the watering place (recreational pond) in Dobra (CF25 - 2a) and the artificial reservoir formed by the sand excavation between Nowe Kolnie and Kościerzyce (CE73 - 2b). In Dobra, Potametum praelongi has developed very well for many years, despite of the intensive recreational usage of the pond, and at present it occupies several hundred of square meters (Nowak, Nowak 2004). For the first time the population in Dobra was reported by Schube (1906). The population in the sand excavation is not so extensive. The community occupies about $25 \mathrm{~m}^{2}$ in the south part of the reservoir. The floristic structures of the communities are shown in Table 2, rel. no 20-24.

\begin{tabular}{|c|c|c|c|c|c|}
\hline Location & $\begin{array}{c}\text { Temp. } \\
{\left[{ }^{\circ} \mathrm{C}\right]}\end{array}$ & $\mathrm{pH}$ & $\begin{array}{c}\text { Trans- } \\
\text { parency } \\
{[\mathrm{cm}]}\end{array}$ & $\begin{array}{c}\text { Total P } \\
{\left[\mathrm{mg} / \mathrm{dm}^{3}\right]}\end{array}$ & TSI \\
\hline Dobra & 20.0 & 8.0 & $\begin{array}{c}\text { To the } \\
\text { bottom } \\
(50-100)\end{array}$ & 0.380 & 80 \\
\hline between Nowe Kolnie & 22.0 & 8.2 & 150 & 0.178 & 69 \\
\hline
\end{tabular}

and Kościerzyce

\section{Potamoetum alpini Br.-Bl. 1949}

The association with the dominance of Potamogeton alpinus was found in the drainage ditch and the fish-pond to the south from Prószków (CF04 - 3a), as well as in channels, ditches, shallow pools and the sand-pit in Kotlarnia and Ortowice (CF48 - 3b). The community occupies large areas in all locations, however the coverage of $P$. alpinus in the sand-pit is significantly greater and reaches up to 90\% (Table 2, rel. no 1-12).

\begin{tabular}{lccccc} 
Location & $\begin{array}{c}\text { Temp. } \\
{\left[{ }^{\circ} \mathrm{C}\right]}\end{array}$ & $\mathrm{pH}$ & $\begin{array}{c}\text { Trans- } \\
\text { parency } \\
{[\mathrm{cm}]}\end{array}$ & $\begin{array}{c}\text { Total P } \\
{\left[\mathrm{mg} / \mathrm{dm}^{3}\right]}\end{array}$ & TSI \\
\hline Kotlarnia & 20.0 & 7.0 & $\begin{array}{c}\text { To the } \\
\text { bottom } \\
(40-60)\end{array}$ & 0.158 & 67 \\
& & &
\end{tabular}

\section{Potametum acutifolii Segal $1961=$ P. acutifolii Podb. 1967 (V category)}

The association has been known from several places (e.g. Schube 1903, 1905). In last years it was confirmed only in the ox-bow lake of the Nysa Kłodzka river near Skorogoszcz (Kozak et al. 2005). Moreover, during the studies large patches of this community were found in the shallow inner-forest pond at Matylda temple to the south from Winna Góra (CE75 - 4), (Table, rel. no 10-13).

\begin{tabular}{lccccc} 
Location & $\begin{array}{c}\text { Temp. } \\
{\left[{ }^{\circ} \mathrm{C}\right]}\end{array}$ & $\mathrm{pH}$ & $\begin{array}{c}\text { Trans- } \\
\text { parency } \\
{[\mathrm{cm}]}\end{array}$ & $\begin{array}{c}\text { Total P } \\
{\left[\mathrm{mg} / \mathrm{dm}^{3}\right]}\end{array}$ & TSI \\
\hline SW from Winna Góra & 20.4 & 6.5 & $\begin{array}{c}\text { To the } \\
\text { bottom }\end{array}$ & 0.336 & 55
\end{tabular}

\section{Potamogeton berchtoldii community}

So far, the community has never been reported from Opole Silesia. However, this results probably from the easy misidentification of the diagnostic species, especially the problems arise while distinguishing it from Potamogeton pusillus. P. berchtoldii was reported from the region in the first half of the XX century (Oracze by Prudnik - Schube 1930).

Very extensive patches of the community were found in the clay-pit to the south-west from Wysoka (CE79 - 5a). The assemblage of $P$. berchtoldii occupied $10 \mathrm{~m}$ wide zone along the south and west water-sides of the reservoir. The community was also noticed in the marl quarry Odra 1 in Opole (CE95 - 5b). Small patches of the community were found in shallow pools of the quarry in Nowa Wieś (BF47 -5 c, Table 3, rel. no 35-39).

\begin{tabular}{lccccc} 
Location & $\begin{array}{c}\text { Temp. } \\
{\left[{ }^{\circ} \mathrm{C}\right]}\end{array}$ & $\mathrm{pH}$ & $\begin{array}{c}\text { Trans- } \\
\text { parency } \\
{[\mathrm{cm}]}\end{array}$ & $\begin{array}{c}\text { Total P } \\
{\left[\mathrm{mg} / \mathrm{dm}^{3}\right]}\end{array}$ & TSI \\
\hline Opole, Odra 1 quarry & 20.0 & 8,2 & 110 & 0.296 & 76 \\
Wysoka-Dąbrowa & 19.2 & 7.2 & 60 & 0.508 & 64
\end{tabular}

\section{Potametum obtusifolii (Sauer 1937) Neuhäusl $1959=$ P. obtusifolii (Carst. 1954) Segal 1965 (V cat.)}

The community of develops in Opole Silesia in different types of water bodies (Table 3, rel. no 1-9). In Lasowice Małe it occurs in the inner-forest pond used as a fire emergency reservoir (CE77 - 6a). Extensive patches of the community were also found in the fish-pond in Winów (CF05 - 6b), drainage ditches and gravel-pits in Brzezie (CE85 - 6c), small and shallow pools in the marble quarry in Stronie Śląskie (BF37 - 6d), as well as in the shallow, unstable and polluted pool in the arable field in Rusków (CE83 - 6e). The diagnostic species of the community has been found in several reservoirs within the last few years (e.g., Kozak et al. 2005) and it seems to be adapted to anthropogenic pressure.

\begin{tabular}{lccccc} 
Location & $\begin{array}{c}\text { Temp. } \\
{\left[{ }^{\circ} \mathrm{C}\right]}\end{array}$ & $\mathrm{pH}$ & $\begin{array}{c}\text { Trans- } \\
\text { parency } \\
{[\mathrm{cm}]}\end{array}$ & $\begin{array}{c}\text { Total P } \\
{\left[\mathrm{mg} / \mathrm{dm}^{3}\right]}\end{array}$ & TSI \\
\hline Opole, Odra 1 quarry & 20.0 & 8.2 & 110 & 0.296 & 76
\end{tabular}

\section{Potamogeton nodosus community}

The community has not been reported from Opole Silesia, however the diagnostic species was found in Ściborzyce Małe (Schube 1903), probably in the Stradunia river.

At present the community of $P$. nodosus occurs exclusively in standing waters. It was found in clay-pits in Mechnice (CE94 - 7a), where its patch of $100 \mathrm{~m}^{2}$ was documented, and also in gravel-pits in Głębocko (CE92 - 7b), Kantorowice (CE83 - 7c), Dzbanów (BF17 - 7d), and Odra (CF78 - 7e, Table 2, rel. no 25-34).

\begin{tabular}{lccccc} 
Location & $\begin{array}{c}\text { Temp. } \\
{\left[{ }^{\circ} \mathrm{C}\right]}\end{array}$ & $\mathrm{pH}$ & $\begin{array}{c}\text { Trans- } \\
\text { parency } \\
{[\mathrm{cm}]}\end{array}$ & $\begin{array}{c}\text { Total P } \\
{\left[\mathrm{mg} / \mathrm{dm}^{3}\right]}\end{array}$ & TSI \\
\hline Mechnice & 21.5 & 8.2 & 120 & 0.230 & 73 \\
Kantorowice & 21.3 & 8.4 & 150 & 0.184 & 69
\end{tabular}


TABLE 2. Broad-leaved pondweed communities in anthropogenic water bodies in Opole Silesia.

\begin{tabular}{|c|c|c|c|c|c|c|c|c|c|c|c|c|c|c|c|c|}
\hline Succeeding number of relevé & 1 & 2 & 3 & 4 & 5 & 6 & 7 & 8 & 9 & 10 & 11 & 12 & 13 & 14 & 15 & 16 \\
\hline Field number of relevé & 60 & 61 & 35 & 36 & 33 & 34 & 30 & 29 & 57 & 59 & 58 & 56 & 6 & 5 & 19 & 20 \\
\hline Date: day & 13 & 15 & 15 & 15 & 15 & 15 & 15 & 3 & 15 & 15 & 13 & 13 & 27 & 7 & 23 & 10 \\
\hline month & 7 & 9 & 5 & 10 & 5 & 10 & 6 & 11 & 9 & 9 & 7 & 7 & 8 & 7 & 6 & 10 \\
\hline year & 05 & 04 & 05 & 04 & 05 & 04 & 05 & 04 & 04 & 04 & 05 & 05 & 04 & 02 & 05 & 04 \\
\hline Location & $\mathrm{P}$ & $\mathrm{P}$ & $\mathrm{O}$ & $\mathrm{O}$ & $\mathrm{O}$ & $\mathrm{O}$ & $\mathrm{K}$ & $\mathrm{K}$ & $\mathrm{P}$ & $\mathrm{P}$ & $\mathrm{P}$ & $\mathrm{P}$ & $\mathrm{Bk}$ & $\mathrm{Bk}$ & $\mathrm{Kt}$ & $\mathrm{Kt}$ \\
\hline Relevé area $\left[\mathrm{m}^{2}\right]$ & 5 & 5 & 15 & 15 & 15 & 15 & 15 & 15 & 10 & 15 & 15 & 10 & 15 & 20 & 10 & 10 \\
\hline Density of shrub layer (b) in $\%$ & - & - & - & - & 15 & - & - & - & - & - & - & - & - & - & - & - \\
\hline Cover of herb layer (c) in $\%$ & 80 & \#\# & 90 & 80 & 80 & 45 & 45 & 70 & 75 & 65 & 60 & 60 & 35 & 30 & 40 & 35 \\
\hline Usage type & $\mathrm{r}$ & $\mathrm{r}$ & ko & ko & ko & ko & wp & wp & $\mathrm{sr}$ & $\mathrm{sr}$ & $\mathrm{sr}$ & $\mathrm{sr}$ & $\dot{\mathrm{z}}$ & $\dot{\mathrm{z}}$ & wp & wp \\
\hline Depth $[\mathrm{m}]$ & 0 & 0 & 0 & 0 & 0 & 0 & 1 & 1 & 1 & 1 & 1 & 1 & 1 & 1 & 1 & 1 \\
\hline Number of species & 7 & 8 & 7 & 6 & 9 & 5 & 8 & 8 & 6 & 7 & 7 & 6 & 4 & 4 & 6 & 5 \\
\hline \multicolumn{17}{|l|}{ D. Com. with Potamogeton alpinus } \\
\hline Potamogeton alpinus & 4 & 5 & 4 & 4 & 4 & 3 & 3 & 3 & 4 & 3 & 3 & 3 & - & - & - & - \\
\hline D. Com. with Potamogeton perfoliatus & & & & & & & & & & & & & & & & \\
\hline Potamogeton perfoliatus & - & - & - & - & - & - & - & - & - & - & - & - & 3 & 2 & 2 & 2 \\
\hline Ch. Ass. Potametum praelongi & & & & & & & & & & & & & & & & \\
\hline Potamogeton praelongus & - & - & - & - & - & - & - & - & - & - & - & - & - & - & - & - \\
\hline D. Com. with Potamogeton nodosus & & & & & & & & & & & & & & & & \\
\hline Potamogeton nodosus & - & - & - & - & - & - & - & - & - & - & - & - & - & - & - & - \\
\hline \multicolumn{17}{|l|}{ Ch. All. Potamion } \\
\hline Potamogeton pectinatus & - & - & - & - & - & - & - & - & - & - & - & - & + & + & + & - \\
\hline Potamogeton pusillus s. str. & - & - & - & - & - & - & - & - & - & - & - & - & - & - & - & - \\
\hline \multicolumn{17}{|l|}{ Ch. O., Cl. Potametalia, Potametea } \\
\hline Myriophyllum verticillatum & - & - & - & - & - & - & - & - & - & - & - & - & - & - & - & - \\
\hline Ceratophyllum demersum & - & - & 1 & + & + & - & $\mathrm{r}$ & 1 & - & - & - & - & - & - & 1 & 1 \\
\hline Myriophyllum spicatum & - & - & - & - & - & - & + & - & 1 & 1 & + & + & + & 1 & 2 & 1 \\
\hline Potamogeton crispus & - & - & - & - & - & - & - & - & - & 2 & 1 & - & - & - & - & - \\
\hline Elodea canadensis & - & - & 2 & 1 & - & - & - & - & - & - & - & - & - & - & - & - \\
\hline Batrachium circinatum & - & - & - & - & - & - & - & - & - & - & - & - & + & + & - & - \\
\hline Potamogeton obtusifolius & - & - & - & - & - & - & - & - & 1 & 1 & 2 & 2 & - & - & - & - \\
\hline Potamogeton natans & - & - & - & - & - & - & - & - & - & - & - & - & - & - & - & - \\
\hline Nuphar lutea & - & - & - & - & - & - & - & - & - & - & - & - & - & - & - & - \\
\hline Polygonum amphibium $\mathrm{f}$. natans & - & - & + & + & - & - & - & - & - & - & - & - & - & - & - & - \\
\hline Potamogeton lucens & - & - & - & - & - & - & - & - & - & - & - & - & - & - & - & - \\
\hline \multicolumn{17}{|l|}{ Accompanying } \\
\hline Phragmites australis $[\mathrm{Ph}]$ & - & - & - & - & - & - & - & + & + & + & + & 1 & - & - & 1 & + \\
\hline Lemna minor $[\mathrm{L}]$ & - & - & 1 & 1 & 1 & + & - & - & - & - & - & - & - & - & - & - \\
\hline Typha latifolia $[\mathrm{Ph}]$ & - & - & - & - & + & + & + & + & - & - & - & - & - & - & + & $\mathrm{r}$ \\
\hline Alisma plantago-aquatica $[\mathrm{Ph}]$ & + & 1 & - & - & - & - & - & - & + & - & + & + & - & - & - & - \\
\hline Callitriche palustris & - & - & + & 1 & 2 & 1 & 1 & 1 & - & - & - & - & - & - & - & - \\
\hline Lycopus europaeus [A] & + & + & - & - & - & - & + & + & - & - & - & + & - & - & - & - \\
\hline
\end{tabular}

\section{Potametum perfoliati W. Koch 1926 em. Pass. 1964}

The community of Potamogeton perfoliatus was found in gravel-pits in Buków (CF77 - 8a) and Kantorowice (CE83 $-8 b$ ), where it was scattered all over the shallow littoral of the reservoirs. It was also noticed in the dammed reservoir in Pławniowice near the village of Niewiesze (CF39 - 8c, Table 3, rel. no 13-19).

\begin{tabular}{lccccc} 
Location & $\begin{array}{c}\text { Temp. } \\
{\left[{ }^{\circ} \mathrm{C}\right]}\end{array}$ & $\mathrm{pH}$ & $\begin{array}{c}\text { Trans- } \\
\text { parency } \\
{[\mathrm{cm}]}\end{array}$ & $\begin{array}{c}\text { Total P } \\
{\left[\mathrm{mg} / \mathrm{dm}^{3}\right]}\end{array}$ & TSI \\
\hline Kantorowice & 21.3 & 8.4 & 150 & 0.184 & 69
\end{tabular}

\section{Potamogeton pusillus community}

The community of $P$. pusillus s. str. belongs to the one of the most frequently occurring in anthropogenic waters in the region. Mostly, it formed loose assemblages in shallow waters of artificial excavations, like in Opole-Wójtowa Wieś (CE95 - 9a), the gravel-pit in Opole-Malina (CF05 - 9b), the gneiss quarry in Doboszowice $(B F 18-9 c)$, the gravel-pit in Odra (CF78 - 9d), shallow pools of the sandpit in Kotlarnia (CF48 - 9e), shallow pools and drainage ditches of the marl quarry in Górażdże (CF16 - 9f), the stone quarry in Nowy Waliszów (BF37 - 9g), the clay-pit to the north-west from Wierzbięcice (CF21 - 9h), as well as in fish-ponds in Jarnołtówek (CF41 - 9i) and Tułowice (Loża; CF03 - 9j, Table 3, rel. no 18-34).

\begin{tabular}{lccccc} 
Location & $\begin{array}{c}\text { Temp. } \\
{\left[{ }^{\circ} \mathrm{C}\right]}\end{array}$ & $\mathrm{pH}$ & $\begin{array}{c}\text { Trans- } \\
\text { parency } \\
{[\mathrm{cm}]}\end{array}$ & $\begin{array}{c}\text { Total P } \\
{\left[\mathrm{mg} / \mathrm{dm}^{3}\right]}\end{array}$ & TSI \\
\hline Opole-Wójtowa Wieś & 20.0 & 7.9 & 100 & 0.286 & 76
\end{tabular}

\section{DISCUSSION}

While investigating the distribution of the rare and threatened pondweed communities in anthropogenic water bodies in Opole Silesia, it is apparently visible that reser- 
TABLE 2. Cont.

\begin{tabular}{|c|c|c|c|c|c|c|c|c|c|c|c|c|c|c|c|c|c|c|c|c|c|}
\hline 17 & 18 & 19 & 20 & 21 & 22 & 23 & 24 & 25 & 26 & 27 & 28 & 29 & 30 & 31 & 32 & 33 & 34 & C & C & $\mathrm{O}$ & $\mathrm{O}$ \\
\hline 38 & 39 & 37 & 25 & 26 & 66 & 24 & 23 & 44 & 45 & 15 & 16 & 17 & 18 & 43 & 22 & 21 & 42 & $\mathrm{O}$ & $\mathrm{O}$ & C & C \\
\hline 15 & 15 & 12 & 15 & 15 & 15 & 17 & 14 & 24 & 17 & 10 & 23 & 10 & 23 & 8 & 19 & 15 & 14 & $\mathrm{~N}$ & $\mathrm{~N}$ & C & C \\
\hline 6 & 6 & 7 & 8 & 6 & 6 & 7 & 8 & 8 & 8 & 10 & 6 & 10 & 6 & 8 & 6 & 6 & 10 & $\mathrm{~S}$ & $\mathrm{~S}$ & U & U \\
\hline 05 & 05 & 03 & 04 & 05 & 05 & 05 & 04 & 03 & 05 & 04 & 05 & 04 & 05 & 04 & 05 & 04 & 03 & $\mathrm{~T}$ & $\mathrm{~T}$ & $\mathrm{R}$ & $\mathrm{R}$ \\
\hline $\mathrm{N}$ & $\mathrm{N}$ & $\mathrm{N}$ & Do & Do & Do & S-K & S-K & $\mathrm{Oz}$ & $\mathrm{Oz}$ & Gł & Gł & $\mathrm{Kt}$ & $\mathrm{Kt}$ & M & $\mathrm{Dz}$ & Dz & M & A & A & $\mathrm{R}$ & R. \\
\hline 10 & 5 & 10 & 50 & 50 & 15 & 5 & 5 & 15 & 15 & 10 & 10 & 5 & 5 & 10 & 5 & 5 & 10 & $\mathrm{~N}$ & $\mathrm{~N}$ & E & \\
\hline- & - & - & - & - & - & - & - & - & - & - & - & - & - & - & - & - & - & C & C & $\mathrm{N}$ & $\mathrm{N}$ \\
\hline 65 & 60 & 15 & 90 & 90 & 60 & 35 & 20 & 70 & 75 & 70 & 60 & 40 & 45 & 30 & 35 & 75 & 45 & $\mathrm{Y}$ & Y & C & $\mathrm{O}$ \\
\hline $\mathrm{zZ}$ & $\mathrm{zZ}$ & $\mathrm{zZ}$ & ką & ką & $\mathrm{kd}$ & wp & wp & $\dot{\mathrm{z}}$ & $\dot{\mathrm{z}}$ & $\dot{\mathrm{Z}}$ & $\dot{z}$ & $\dot{\mathrm{z}}$ & $\dot{\mathrm{z}}$ & $\mathrm{g}$ & $\dot{\mathrm{z}}$ & $\dot{\mathrm{z}}$ & $\mathrm{g}$ & & & E & \\
\hline 1 & 1 & 0 & 1 & 1 & 1 & 1 & 1 & 1 & 1 & 0 & 0 & 1 & 1 & 1 & 1 & 1 & 1 & & & $\mathrm{~N}$ & \\
\hline 6 & 8 & 4 & 5 & 5 & 7 & 4 & 7 & 4 & 7 & 7 & 7 & 4 & 3 & 3 & 7 & 6 & 2 & & & $\mathrm{O}$ & \\
\hline & & & & & & & & & & & & & & & & & & $1-12$ & $13-19$ & $20-24$ & $25-34$ \\
\hline- & - & - & - & - & - & - & - & - & - & - & - & - & - & - & - & - & - & V & - & - & - \\
\hline 3 & 2 & 1 & - & - & - & - & - & - & - & - & - & + & - & - & - & - & - & - & V & - & - \\
\hline- & - & - & 5 & 4 & 3 & 2 & 1 & - & - & - & - & - & - & - & - & - & - & - & - & 5 & - \\
\hline- & - & - & - & - & - & - & - & 4 & 4 & 3 & 2 & 3 & 3 & 2 & 2 & 3 & 3 & - & - & - & V \\
\hline- & - & - & - & - & - & - & + & - & - & + & + & + & + & - & - & - & - & - & III & 1 & II \\
\hline- & - & - & - & - & - & - & - & - & - & - & - & - & - & - & 1 & 2 & - & - & - & - & I \\
\hline 1 & 2 & 1 & + & 1 & 1 & 1 & + & + & + & 1 & + & - & - & - & - & - & - & - & III & 5 & II \\
\hline- & - & - & + & - & - & 1 & 1 & - & - & 1 & + & - & - & - & - & - & - & III & II & 3 & I \\
\hline- & - & - & - & - & - & - & - & - & - & - & - & - & 1 & 1 & - & - & - & III & III & - & I \\
\hline- & - & - & - & - & - & 1 & + & - & - & - & - & - & - & - & 1 & 1 & - & I & - & 2 & I \\
\hline 2 & 1 & - & - & - & - & - & - & - & - & - & - & - & - & - & + & - & - & I & II & - & I \\
\hline 1 & 2 & - & - & - & - & - & 1 & - & - & - & - & - & - & - & - & - & - & - & III & 1 & - \\
\hline- & - & - & - & - & - & - & - & - & - & - & - & - & - & - & - & - & - & II & - & - & - \\
\hline- & - & - & - & - & - & - & - & - & - & - & - & - & - & + & 1 & 2 & + & - & - & - & II \\
\hline- & - & - & $\mathrm{r}$ & 1 & 1 & - & - & - & - & - & - & - & - & - & - & - & - & - & - & 3 & - \\
\hline- & + & - & - & - & - & - & - & - & - & - & - & - & - & - & - & - & - & I & I & - & - \\
\hline- & - & - & - & - & - & - & - & 1 & + & - & - & - & - & - & - & - & - & - & - & - & I \\
\hline+ & + & - & - & - & - & - & - & - & - & - & - & + & - & - & + & + & - & III & III & - & II \\
\hline- & - & - & + & + & + & - & + & + & - & - & - & - & - & - & - & - & - & II & - & 4 & I \\
\hline- & - & - & - & - & - & - & - & - & - & 2 & 2 & - & - & - & - & - & - & II & II & - & I \\
\hline- & - & - & - & - & + & - & - & - & + & - & - & - & - & - & + & - & - & III & - & 1 & I \\
\hline- & - & - & - & - & - & - & - & - & - & - & - & - & - & - & - & - & - & III & - & - & - \\
\hline- & - & + & - & - & - & - & - & - & - & - & - & - & - & - & - & - & - & III & I & - & - \\
\hline
\end{tabular}

Sporadic species (cover in + if not indicated otherwise): Ch. All. Potamion: Potamogeton berchtoldii 3; Ch. O., Cl. Potametalia, Potametea: Trapa natans 11; Accompanying: Alopecurus geniculatus [MA] 1(1), 2; Bidens cernua [B] 1(1), 2; Carex appropinquata [Ph] 5(r); Elatine hexandra [IN] 27(1), 28(1); E. triandra [IN] 27(1), 28(2); Equisetum fluviatile [Ph] 7, 8(1); Glyceria fluitans [Ph] 1(1), 2(1); G. maxima [Ph] 22(1); Juncus articulatus [SC] 7(1), 8(2), 26(1); Juncus conglomeratus [MA] 5, 6, 33; Lythrum salicaria [MA] 1, 2(1); Mentha aquatica 17, 18; Oenanthe aquatica [Ph] 21, 22(1); Padus serotina b 5(2); Phalaris arundinacea $[\mathrm{Ph}]$ 9(1), 10, 18, 19, 26; Ranunculus repens $[\mathrm{MA}] 2$; Rorippa amphibia $[\mathrm{Ph}] 26$; Salix caprea $\mathrm{b}[\mathrm{E}]$ 5; Sparganium erectum $[\mathrm{Ph}] 10$.

Locations: 1, 2, 9, 10, 11, 12 - Prószków (P); 3, 4, 5, 6 - Ortowice (O); 7, 8 - Kotlarnia (K); 13,14 - Buków (Bk); 15, 16, 29, 30 - Kantorowice (Kt); 17, 18, 19 - Niewiesze (N); 20, 21, 22 - Dobra (Do); 23, 24 - between Stare Kolnie and Kościerzyce (S-K); 25, 26 - Olza (Oz); 27, 28 - Głębocko (Gł); 31 , 34 - Mechnice (M); 32, 33 - Dzbanów (Dz).

Usage type: g - clay-pit; ką - recreation pond; kd - influent channel; ko - surrounding channel; $\mathrm{r}$ - drainage ditch; sr - fish culture pond; wp - sand-pit; zZ - dammed reservoir; $\dot{\mathrm{z}}$ - gravel-pit.

Explanations: $[\mathrm{A}]$ - Alnetea glutinosae; [B] - Bidentetea; [E] - Epilobietea angustifolii; [IN] - Isoëto-Nanojuncetea; [L] - Lemnetea; [MA] - MolinioArrhenatheretea; [Ph] - Phragmitetea; [SC] - Scheuchzerio-Caricetea.

voirs created as a result of economic activity of man (agriculture, fishery, mining or melioration) could serve as a suitable habitat for plant communities, very interesting from the conservation as well as syntaxonomical point of view. The more so as we consider the problem of disap- pearance of the rare pondweed communities from their natural reservoirs, like ox-bow lakes in river valleys. The lack of confirmation of these water plants in ox-bow lakes results from long-term river-control works, an extensive eutrophication of river valleys, an intensive agriculture and 
TABLE 3. Narrow-leaved pondweed communities in anthropogenic water bodies in Opole Silesia.

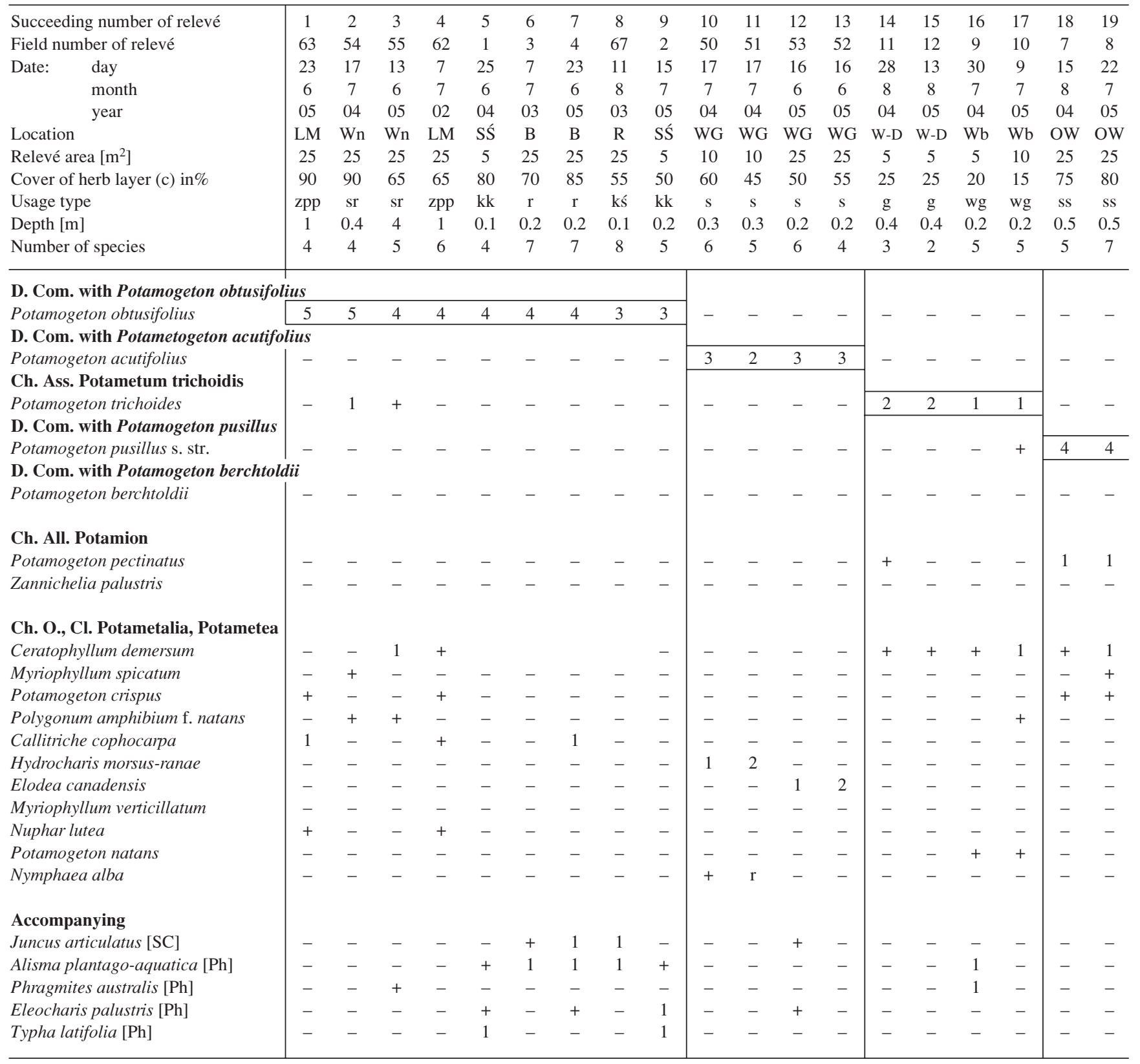

also floods which increase in dynamic and strength because of the anti-flooding policy of water authorities. The floodpulse caused by the sudden input of surface water will probably wash out most of the hydrophytes and it is very likely that the rare species with their low recolonization strategies will disappear in these conditions (Vanderpoorten and Klein 1999).

Water reservoirs in sand-pits, gravel-pits and quarries should be regarded as the richest from the syntaxonomical point of view. In comparison to the fish culture ponds, these types of water bodies have a lower trophic level and resist anthropogenic pressure. They are located in restricted areas, though closed to the public and with no possibility to use them for fishery, angling and recreational purposes. The excavations are often surrounded by broad buffer zones which prevent waters from nutrient flow. The excessive manure and fertilizer application usually leads to nitrate $\left(\mathrm{NO}_{3}^{-}\right)$leaching from the agricultural land to groundwaters and surface waters (typical for fish-ponds and ox-bow lakes). As a consequence, many shallow freshwater ecosystems suffer from high $\mathrm{NO}_{3}{ }^{-}$loading (100-1000 $\mu \mathrm{m} / \mathrm{l})$. Thus rooted and submerged macrophytes potentially have to face an excessive $\mathrm{N}$ assimilation rates. Higher $\mathrm{NH}_{4}{ }^{+}$concentration can reduce the growth and vitality of submerged species, like $P$. alpinus (Boedeltje et al. 2005).

The artificial reservoirs, especially at the beginning of existence, have no stable plant cover and are very suitable for settlement of pioneer plants like $P$. pussilus and $P$. berchtoldii which have a wide ecological amplitude (Pott 1995). The lack or scarcity of rush communities is a cause of insignificant grazing pressure from the aquatic birds which need a shelter from predators. It has been confirmed that grazing (e.g. by Anas platyrhynchos) may have a negative influence on macrophyte communities even if waterfowl density is relatively low (Lauridsen et al. 2003).

Typical pondweed communities developing almost exclusively in gravel-pit waters are $P$. nodosus and $P$. perfoliatus assemblages. $P$. nodosus is considered as polluto- 
TABLE 3. Cont.

\begin{tabular}{cccccccccccccccccccccccccc}
\hline 20 & 21 & 22 & 23 & 24 & 25 & 26 & 27 & 28 & 29 & 30 & 31 & 32 & 33 & 34 & 35 & 36 & 37 & 38 & 39 & $\mathrm{C}$ & $\mathrm{O}$ & $\mathrm{O}$ & $\mathrm{C}$ & $\mathrm{O}$ \\
72 & 73 & 31 & 70 & 27 & 28 & 74 & 75 & 41 & 71 & 68 & 69 & 49 & 40 & 32 & 13 & 14 & 46 & 48 & 47 & $\mathrm{O}$ & $\mathrm{C}$ & $\mathrm{C}$ & $\mathrm{O}$ & $\mathrm{C}$ \\
7 & 15 & 14 & 24 & 3 & 15 & 23 & 23 & 10 & 17 & 30 & 9 & 3 & 17 & 19 & 28 & 13 & 18 & 31 & 31 & $\mathrm{~N}$ & $\mathrm{C}$ & $\mathrm{C}$ & $\mathrm{N}$ & $\mathrm{C}$ \\
7 & 6 & 7 & 8 & 11 & 6 & 9 & 9 & 8 & 8 & 7 & 7 & 6 & 6 & 6 & 8 & 8 & 9 & 6 & 6 & $\mathrm{~S}$ & $\mathrm{U}$ & $\mathrm{U}$ & $\mathrm{S}$ & $\mathrm{U}$ \\
04 & 05 & 03 & 03 & 04 & 05 & 04 & 04 & 05 & 05 & 04 & 05 & 04 & 04 & 05 & 04 & 05 & 04 & 05 & 05 & $\mathrm{~T}$ & $\mathrm{R}$ & $\mathrm{R}$ & $\mathrm{T}$ & $\mathrm{R}$ \\
$\mathrm{OM}$ & $\mathrm{OM}$ & $\mathrm{D}$ & $\mathrm{Oz}$ & $\mathrm{K}$ & $\mathrm{K}$ & $\mathrm{J}$ & $\mathrm{J}$ & $\mathrm{G}$ & $\mathrm{Oz}$ & $\mathrm{Wb}$ & $\mathrm{Wb}$ & $\mathrm{G}$ & $\mathrm{NW}$ & $\mathrm{D}$ & $\mathrm{W}$ & $\mathrm{W}$ & $\mathrm{NW}$ & $\mathrm{NW}$ & $\mathrm{NW}$ & $\mathrm{A}$ & $\mathrm{R}$ & $\mathrm{R}$ & $\mathrm{A}$ & $\mathrm{R}$. \\
5 & 5 & 5 & 5 & 5 & 5 & 5 & 5 & 5 & 5 & 5 & 5 & 5 & 5 & 5 & 25 & 25 & 5 & 5 & 10 & $\mathrm{~N}$ & & & $\mathrm{~N}$ & \\
25 & 30 & 25 & 50 & 40 & 25 & 80 & 95 & 45 & 60 & 30 & 40 & 25 & 25 & 20 & 90 & 75 & 45 & 70 & 20 & $\mathrm{C}$ & $\mathrm{N}$ & $\mathrm{N}$ & $\mathrm{C}$ & $\mathrm{N}$ \\
$\dot{\mathrm{z}}$ & $\dot{\mathrm{z}}$ & $\mathrm{kg}$ & $\dot{\mathrm{z}}$ & $\mathrm{kp}$ & $\mathrm{kp}$ & $\mathrm{sr}$ & $\mathrm{sr}$ & $\mathrm{kk}$ & $\dot{\mathrm{z}}$ & $\mathrm{wg}$ & $\mathrm{wg}$ & $\mathrm{kk}$ & $\mathrm{zwk}$ & $\mathrm{kg}$ & $\mathrm{g}$ & $\mathrm{g}$ & $\mathrm{kk}$ & $\mathrm{kk}$ & $\mathrm{kk}$ & $\mathrm{Y}$ & $\mathrm{O}$ & $\mathrm{O}$ & $\mathrm{Y}$ & $\mathrm{O}$ \\
0.5 & 0.5 & 0.4 & 0.3 & 0.1 & 0.1 & 1 & 1 & 0.2 & 0.3 & 0.2 & 0.2 & 0.2 & 0.8 & 0.4 & 0.6 & 0.6 & 0.1 & 0.1 & 0.1 & & & & & \\
5 & 5 & 4 & 9 & 6 & 6 & 5 & 5 & 4 & 8 & 5 & 6 & 5 & 8 & 5 & 2 & 2 & 5 & 9 & 5 & & & & & &
\end{tabular}

\begin{tabular}{|c|c|c|c|c|c|c|c|c|c|c|c|c|c|c|c|c|c|c|c|c|c|c|c|c|}
\hline & & & & & & & & & & & & & & & & & & & & $(1-9)$ & $(10-13)$ & $(14-17)$ & (18-34) & $(35-39)$ \\
\hline- & - & - & - & - & - & - & - & - & - & - & - & - & - & - & - & - & - & - & - & $\mathrm{V}$ & - & - & - & - \\
\hline- & - & - & - & - & - & - & - & - & - & - & - & - & - & - & - & - & - & - & - & - & 4 & - & - & - \\
\hline - & - & - & - & - & - & - & - & - & - & - & + & - & - & - & - & - & - & - & - & II & - & 4 & - & - \\
\hline 2 & 2 & 2 & 3 & 3 & 2 & 3 & 4 & 3 & 3 & 2 & 3 & 2 & 2 & 2 & - & - & - & - & - & - & - & 1 & V & - \\
\hline- & - & - & - & - & - & - & - & - & - & - & - & - & - & - & 5 & 4 & 3 & 3 & 2 & - & - & - & - & 5 \\
\hline 1 & 1 & 1 & + & - & - & - & - & - & - & - & - & - & - & - & - & - & - & - & - & - & - & 1 & II & - \\
\hline - & - & - & - & + & + & - & - & - & - & - & - & - & - & - & - & - & - & - & - & - & - & - & I & - \\
\hline - & - & - & - & 1 & 1 & - & - & - & - & - & - & - & - & - & - & 1 & - & - & - & II & - & 4 & II & 1 \\
\hline+ & 1 & - & + & + & + & 2 & + & - & - & - & - & - & - & - & - & - & - & - & - & I & - & - & III & - \\
\hline - & - & - & + & - & - & - & - & - & - & - & - & - & - & - & - & - & - & - & - & II & - & - & I & - \\
\hline - & - & _ & - & - & - & - & - & _ & - & + & + & - & - & - & - & - & - & - & - & II & - & 1 & I & - \\
\hline - & - & _ & - & - & - & - & - & _ & - & - & - & - & - & - & - & - & - & - & - & II & - & - & - & - \\
\hline - & - & - & - & - & - & - & - & - & - & - & - & - & - & - & - & - & - & - & - & - & 2 & - & - & - \\
\hline - & - & - & - & - & - & - & - & - & - & - & - & - & - & - & - & - & - & - & - & - & 2 & - & - & - \\
\hline - & - & - & 1 & - & - & - & - & - & 1 & - & - & - & - & - & - & - & - & - & - & - & - & - & I & - \\
\hline - & - & - & - & - & - & - & - & - & - & - & - & - & - & - & - & - & - & - & - & II & - & - & - & - \\
\hline - & - & - & - & - & - & - & - & - & - & - & - & - & - & - & - & - & - & - & - & - & - & 2 & - & - \\
\hline- & - & - & - & - & - & - & - & - & - & - & - & - & - & - & - & - & - & - & - & - & 2 & - & - & - \\
\hline- & + & - & 1 & + & - & - & - & 1 & 1 & - & - & - & + & - & - & - & 1 & + & - & II & 1 & - & II & 2 \\
\hline - & - & + & - & - & - & - & - & - & + & 1 & - & - & + & + & - & - & - & 1 & - & III & - & 1 & II & 1 \\
\hline+ & - & - & - & - & - & 1 & + & + & 1 & 1 & + & + & - & - & - & - & - & - & - & I & - & 1 & III & - \\
\hline - & - & + & - & - & - & - & - & - & - & - & - & - & + & + & - & - & - & - & - & II & 1 & - & I & - \\
\hline - & - & - & - & - & + & - & - & - & - & - & - & - & + & + & - & - & + & - & $\mathrm{r}$ & II & - & - & I & 2 \\
\hline
\end{tabular}

Sporadic species (cover in + if not indicated otherwise): Ch. All. Potamion: Najas marina 29; Ch. O., Cl. Potametalia, Potametea: Potamogeton lucens 4; Accompanying: Agrostis stolonifera [MA] 8, 33, 34; Alopecurus geniculatus [MA] 8(1); Bidens cernua [B] 8; B. tripartita [B] 26, 32, 33, 37, 38, 39; Calamagrostis canescens [A] 6; Callitriche palustris 24; Callitriche stagnalis 38(2); Carex pseudocyperus [Ph] 10, 11, 12(1), 35(r); Chara sp. [Ch] 10(2), 11(1), 26(2), 27(3), 30, 31; Epilobium hirsutum [Ar] 6, 7; E. palustre 33(r), 38; Equisetum fluviatile [Ph] 25; Glyceria maxima [Ph] 6, 7(1), 38(1); Hydrocotyle vulgaris $[\mathrm{SC}] 12$, 13; Lapsana communis $[\mathrm{Sm}]$ 8; Lemna minor $[\mathrm{L}]$ 19, 23; Lycopus europaeus $[\mathrm{A}]$ 20, 21, 23, 29(1), 31; Oenanthe aquatica $[\mathrm{Ph}] 27$; Phalaris arundinacea $[\mathrm{Ph}]$ 8, 23; Potentilla anserina $[\mathrm{MA}]$ 9; Ranunculus flammula $[\mathrm{SC}] 6$; Rorippa amphibia $[\mathrm{Ph}]$ 29; Schoenoplectus tabernaemontani $[\mathrm{Ph}]$ 32(1); Sparganium emersum $[\mathrm{Ph}]$ 10, 13; Sparganium erectum $[\mathrm{Ph}]$ 39(r); Spirodela polyrhiza $[\mathrm{L}]$ 18, 19; Stellaria uliginosa 38(1); Tussilago farfara [Sm] 37, 39; Typha laxamnnii [Ph] 28(1), 32(1); Veronica beccabunga $[\mathrm{Ph}] 38$.

Locations: 1, 4 - Lasowice Małe (LM); 2, 3 - Winów (Wn); 5, 9 - Stronie Śląskie (SŚ); 6, 7 - Brzezie (B); 8 - to the S from Rusków (R); 10, $11,12,13$ Winna Góra (WG); 14, 15 - Wysoka - Dąbrowa (W-D); 16, 17, 30, 31 - to the NW from Wierzbięcice (Wb); 18, 19 - Opole-Wójtowa Wieś (OW); 20,21 - Opole-Malina (OM); 22, 34 - Doboszowice (D); 23, 29 - Olza (Oz); 24, 25 - Kotlarnia (K); 26, 27 - Jarnołtówek (J); 28,32 - Górażdże (G); 33 Nowy Waliszów (NW); 35, 36 - to the SW from Wysoka (W); 37, 38, 39 - Nowa Wieś (NW); Usage type: g - clay-pit; kg - gneiss quarry; kk - pool in quarry; kp - pool in sand-pit; kś - mid-field pool; $\mathrm{r}$ - drainage ditch; $\mathrm{s}$ - small pond; $\mathrm{sr}$ - fish culture pond; ss - artificial ox-bow lake; wg - earthworks in clay-pit; zpp - fire emergency reservoir; zwk - melioration reservoir in quarry; $\dot{z}$ - gravel-pit.

Explanations: $[\mathrm{Ar}]$ - Artemisietea; $[\mathrm{Ch}]$ - Charetea; [Sm] - Stellarietea mediae; others like in Table 2.

tolerant species (Vanderpoorten, Klein 1999). It has occured quite often in Iowa (USA), being third in respect of abundance, after Typha and Scirpus species, in shallow eutrophic lakes within the agricultural areas (Eggers et al.
2004). It has been reported from anthropogenic water bodies in the upper Rhine main channel and side-channels (Vanderpoorten and Klein 1999) and also from irrigation canals in the Nile Delta (Khedr and El-Demerdash 1997). 
Drainage ditches and channels can also offer very suitable conditions for the development of rare pondweed communities. Such habitats are often completely overgrown by phytocoenoses of $P$. obtusifolius (Brzezie) and $P$. alpinus (Prószków, Kotlarnia). For many species the adaptation to anthropogenic habitats could be the last chance of surviving. $P$. alpinus association, previously quite common in Danish lakes and streams, has significantly decreased and now occurs infrequently (Sand-Jensen et al. 2000). It has also decreased in England (Preston 1995), the Netherlands (Mesters 1995) and Finland (Kurimo 1979; Rintanen 1996). The communities of $P$. alpinus and $P$. acutifolius are known from drainage ditches and channels from the central part of Poland (Podbielkowski 1967).

Potamogeton trichoides builds the community on sandy or peaty bottoms, in still, clear, mesotrophic to eutrophic waters of small and shallow (1-2 m) reservoirs, often with a wide water-level range. Potametum trichoidis has a low competitive potential and sometimes temporary and pioneering character (Pott 1995; Schubert et al. 1995). Characteristic species has been considered as an extremely endangered in the Sudeten Mts. (Fabiszewski and Kwiatkowski 2002). The Opole Silesian populations confirm the pioneering and temporary character of this association. It does not occur in older reservoirs, only the diagnostic species has been sporadically found as an additional and scarce component of the other pondweed communities, e.g. $P$. obtusifolii in the fish-pond in Winów. The community prefers warm waters and consists of a few species. In central Europe, the association is quite common in the Danube delta (Cristofor et al. 2003).

The population of $P$. praelongus occurring in the recreational pond in Dobra is an example of the specific adaptation to environmental conditions. The community and its diagnostic species has been considered as most at risk within large areas of its former distribution range in Europe (Schubert et al. 1995), as well as in Poland. The community of $P$. praelongus is characteristic for very clear waters (Matuszkiewicz 2001; Pott 1995) and its distribution is limited in many European countries (e.g., Rintanen 1996; Riis et al. 2000; Sand-Jensen et al. 2000; Preston 1995; Mesters 1995; Procházka and Rydlo 2001). However, in the locations in Opole Silesia, the community is very rare and exists in extremely disturbed and also temporarily polluted habitats, in very eutrophic conditions with significant direct human pressure (Nowak and Nowak 2004). As rural development and roads surround the pond in Dobra, domestic sewages have been discharged into the water until quite lately. Due to this, the water is transparent and clear only in early spring and autumn. Annual reservoir liming, at the end of winter, is one of the reasons for the high $\mathrm{pH}$ value $(\mathrm{pH})$. Moreover, the submerged $P$. praelongus meadow has been occasionally mowed by the pond owner. There are only few other sites of $P$. praelongus occurrence in man-made water bodies, e.g. in cooling reservoirs of electric power plants in Canada (Taylor and Helwig 1995). However, the species retreats also in its American range (Eggers et al. 2004).

Potametum praelongi is considered as an extremely endangered association in central Europe. It is regarded as the typical one for cold, clear, alkaline, and meso- or eutrophic waters, both standing and flowing (Pott 1995; Schubert et al. 1995). According to Matuszkiewicz (2001),
Potamogeton praelongus is the characteristic species for the Potametum filiformis association occurring in clear, cold, standing or slowly running mesotrophic waters. In Opole Silesia it creates the species-poor community, that is absolutely dominated by the diagnostic taxon. With regard to the analysis of the structure and physiognomy of the phytocoenosis and the diagnostic species, as well as to the significant contribution of the Nymphaeion species, it would be reasonable to reconsider the syntaxonomical position of the community. Vahle and Preising (1990) and Pott (1995) have included it into Potametum lucentis.

Potametum alpini develops in standing or slowly running mesotrophic waters, with low calcium content. However, it may inhabit a wide range of freshwater habitats, less than $1.5 \mathrm{~m}$ depth. It grows in mesotrophic or eutrophic waters revealing from slightly acidic to moderately alkaline reaction, and on various substrata, like peat, sand, loam or clay (Wiegleb and Todeskino 1983; Preston 1995; Preston and Croft 1997). Probably the community suffers because of pollution and eutrophication (Pott 1995; Preston and Croft 1997; Sand-Jensen 2000; Riis and Sand-Jensen 2001). Podbielkowski (1967) found this association in drainage ditches in the peatland area near Warsaw. They were characterized by slowly running water of $15-20 \mathrm{~cm}$ depth, $\mathrm{pH} 7-9$, and the mean value of species richness about 5 . The community is assumed to be expansive with a high recovery potential.

According to Matuszkiewicz (2001), Potamogeton alpinus is the characteristic species for Potametum filiformis, occurring in clear, cold and standing or slowly running mesotrophic waters. Pott (1995) also indicates this taxon as weakly characteristic for P. filiformis, but only for the Alpine region. Considering recommendations of Pott (1995) and Matuszkiewicz (2001) on the narrow and precise classification of pondweed communities, as well as doubts of Tomaszewicz (1979) about unifying $P$. alpinus and $P$. filiformis stands into one syntaxon, it seems reasonable to classify the $P$. alpinus community as the separate association. In Opole Silesia $P$. alpinus creates large populations with a visible dominance and a high cover rate, without co-occurrence of other diagnostic or different pondweed species (Table 2).

The Silesian population of $P$. alpinus is characterised by the lowest thermal requirements among the investigated pondweed communities, which probably result from its adaptation to cold running waters. The association has the highest species richness as well.

Recently, significant changes have been observed in fishponds. Due to intensive fishery and introduction of phytophagous species, like the grass carp (Ctenopharyngodon idella), habitat conditions have become unfavourable for rare and threatened pondweed communities. Clearance of surrounding rushes and the water plant cover also causes serious damages to pondweed communities, e.g. communities built by $P$. perfoliatus are not able to regrow after cutting (Riis et al. 2000). However, many interesting pondweed associations occur in ponds extensively used for the fire emergency or scenery reasons, e.g., large surface of the pond is covered by $P$. obtusifolius in Lasowice Małe or P. acutifolius in Winna Góra.

$P$. acutifolius community occurs in standing, shallow (up to $1 \mathrm{~m}$ ), small, and eutrophic waters with large mud deposits. It is considered as a very rare and endangered one 
in Germany and Danmark (Pott 1995; Rennwald 2000; Schubert et al. 1995; Sand-Jensen et al. 2000).

In Poland, the association of $P$. acutifolius, vulnarable in Silesia, is also very rare and known only from a few places in the central and North Poland (Matuszkiewicz 2001; Bociag 2003). Podbielkowski (1967) found this community in drainage ditches near Warsaw, revealing the cover rate of $P$. acutifolius up to $100 \%$ and the mean value of the species richness about 5 . The water depth was about $80 \mathrm{~cm}$ and was characterized by a considerably high alcaline reaction $(\mathrm{pH}$ 9). In Opole Silesia this very rare community grows in mesotrophic waters with the lowest $\mathrm{pH}$ value of 6.5. The development of the species requires a significant sunlight availability.

$P$. berchtoldii shows the character of the pioneers, however its range of environmental conditions is wide (Pott 1995). In British Columbia (Canada) the community occurs in standing or slowly running waters $(0.0-0.4 \mathrm{~m} / \mathrm{s}$, mainly up to $1.5 \mathrm{~m}$ depth), on clayey or sandy bottoms (French and Chambers 1996). While in Northern Ireland it has been regarded as quite frequent (Heegaard et al. 2001), in the other European countries it seems to be rare. The community has not been distinguished in Poland because identification of the diagnostic species is problematic, that is quite typical for representatives of Potamogeton genus (e.g. Toma 2002). Syntaxonomy of the community requires a special phytosociological and habitat investigation. For the British Islands, the community is described as $P$. berchtoldii subcommunity of P. perfoliatus-Myriophyllum alternifolium community (Rodwell 2000). In Opole Silesia it sometimes builds almost the monospecies phytocoenosis with the evident domination of the diagnostic $P$. berchtoldii. It forms rather species-poor assemblages in slightly acidic, warm and eutrophic waters.

An association occurring in drainage ditches, ponds and different kind of small water bodies is Potametum obtusifolii. It has been considered as threatened in Germany and characteristic for mesotrophic and shallow water bodies with sandy and loamy bottoms; retreating due to water eutrophication (Pott 1995; Schubert et al. 1995; SolińskaGórnicka and Symonides 2001). Matuszkiewicz (2001) regards this association as rare and typical for eutrophic and clear waters and includes it to the Nymphaeion alliance. In Opole Silesia the characteristic species occurs in mesotrophic waters with scarcity of the other Nymphaeion species. In spite of the high trophy level, the species diversity of the association is low and it has a significant representation of non-Potametea species (a low value of the moisture indicator is caused by the terrestrial species occurrence). Considering the newly found locations of $P$. obtusifolius in different kinds of water habitats, even polluted and degraded (e.g. Kozak et al. 2005), it seems that the species reveals moderate expansion within Opole Silesia. The similar process has been observed in Denmark, where the species has evidently a greater distribution than 100 years ago (Sand-Jensen et al. 2000). It is also quite common in Northern Ireland (Heegaard et al. 2001).

In Opole Silesia $P$. nodosus community occurs in new reservoirs with restricted rush zone and without surrounding forest or shrub vegetation. The water was moderately eutrophic (TSI index ca. 70) and the $\mathrm{pH}$ value was considerably high ( $\mathrm{pH}$ about 8.3 ), similarly to the situation in the
North Africa (Khedr and El-Demerdash 1997). The standing water community of $P$. nodosus has been distinguished in Germany (Rennwald 2000). It has been characterised as a typical for standing or slowly running eu- or mesotrophic water ecosystems, with the loamy or sandy bottom and the depth of 1-4 m (Schubert et al. 1995).

The investigated $P$. perfoliatus phytocoenoses were characterised by the highest values of the diversity index, however, the species richness revealed the middle values. The water is transparent and moderately eutrophic. Although this association has been considered as the threatened in Germany (Rennwald 2000), in the North and central Europe it has been widely distributed and not threatened, e.g. it is a quite common in the North and central Poland, a relatively common in Danish lakes and streams with eutrophic water, and a quite frequently occurring in Northern Ireland (Ciecierska 1998; Matuszkiewicz 2001; Tomaszewicz 1979; Heegaard et al. 2001; Solińska-Górnicka and Symonides 2001; Kraska et al. 2004). The community occurs also in tidal freshwater wetlands in the North-East of the USA (Capers 2003). The high population dynamic of $P$. perfoliatus allowed to use this species even for restoration purposes of shallow eutrophic lakes in Great Britain (Lauridsen et al. 2003).

It is worth to mention that in Opole Silesia $P$. perfoliatus does not occur together with $P$. lucens, which is a typical situation in Germany, thus those species are classified to one association - Potametum lucentis Hueck 1931 (Pott 1995). In Great Britain, Potamogeton perfoliatus as well as $P$. gramineus and Myriophyllum alternifolium form the most consistent floristic element of $P$. perfoliatus- $M$. alternifolium community (Rodwell 2000). This community has been considered as a quite rich and varied pondweed assemblage where, apart from broad-leaved species, many other submerged pondweeds occur, providing significant local diversity in this vegetation, e.g., $P$. pusillus, $P$. berchtoldii, $P$. obtusifolius, $P$. alpinus and $P$. praelongus.

The community of $P$. pusillus develops in small water bodies located on the bottom of the surface excavations, like quarries, gravel-pits and sand-pits. It has a pioneering character and retreats when the increase in water trophy or in competitiveness of the other vegetation types becomes more intense (Pott 1995). The community also suffers from the insulation decrease (Capers 2003). Synantropodynamic status of its is unclear. It seems to be common in excavation waters, but on the other hand, it has disappeared in fish-ponds and the other old reservoirs with high trophy level. In Denmark $P$. pusillus has apparently a wider distribution now than 100 years ago (Sand-Jensen et al. 2000). However, it has been reported that the species revealed the lowest regeneration and recolonisation rate after its disturbance (fragmentation). Survival of all fragments was very low and none of them developed propagules or roots (Barrat-Segretain et al. 1998). Podbielkowski (1967) found $P$. pusillus community in drainage ditches within the peatland area near Warsaw and ranked it among the expansive types of phytocoenoses with the high regeneration potential.

According to the five-degree scale of Jurko (1986), the mean values of the diversity index $(0.65-1.21)$ obtained for the analyzed community patches are considered as very low or low. However, this is typical for such types of water vegetation, for instance, $P$. nodosus assemblages in the Nile delta obtained the mean value of Shannon-Wiener 
index of 1.03 (Khedr and El-Demerdash 1997). Obviously, the species richness of the community was also quite low, revealing the mean value of 5.56. Podbielkowski (1967) described $P$. acutifolius communities with a significantly scarce number of species.

As expected, results of the ecological analysis of habitat conditions, according to indicator values of the separate taxa, revealed that the artificial water bodies favourable for threatened pondweeds were warm waters characterized by a high isolation rate, a low continentality value (subatlantic climate), a very high humidity value, and a relatively high value of the reaction index (close to neutral $\mathrm{pH}$ ).

\section{ACKNOWLEDGEMENTS}

The authors want to thank Joanna Zalewska-Gałosz (Jagiellonian University, Kraków) for the assistance in identification of Potamogeton species and the anonymous reviewer for considerable improvement of the manuscript.

\section{LITERATURE CITED}

BARRAT-SEGRETAIN M.-H., BORNETTE G., HERINGVILAS-BÔAS A. 1998. Comparative abilities of vegetative regeneration among aquatic plants growing in disturbed habitats. Aquatic Botany 60: 201-211.

BERNACKI L., NOWAK T., URBISZ A.N., URBISZ A.L., TOKARSKA-GUZIK B. 2000. Protected, threatened and rare plants in the flora of Silesia province (voivodeship). Acta. Biol. Siles. 35 (52): 78-107.

BOCIAqG K. 2003. The impact of acidic organic matter on the diversity of underwater vegetation in soft water lakes. Acta Soc. Bot. Pol. 72 (3): 221-229.

BOEDELTJE G., SMOLDERS A.J.P., ROELOFS J.G.M. 2005. Combined effect of water column nitrate enrichment, sediment type and irradiance on growth and foliar nutrient concentration of Potamogeton alpinus. Freshwater Biol. 50: 1537-1547.

BRAUN-BLANQUET J. 1964. Pflanzensoziologie, Gründzüge der Vegetationskunde. Dritte Auflage, Springer Verl., Wien-New York. 865 pp.

CAPERS R.S. 2003. Six years of submerged plant community dynamics in a freshwater tidal wetlands. Freshwater Biol. 48: 1640-1651.

CARLSON R.E. 1977. A trophic state index for lakes. Limnol. Oceanogr. 22: 361-369.

CELIŃSKI F., WIKA S., PARUSEL J.B. 1997. Red list of Upper Silesian plant communities. Raporty, Opinie 2: 38-68.

CIECIERSKA H. 1998. Assessment of the degree of synanthropization of vegetation in the urban lakes in Ostróda (Masurian Lake District). Acta Soc. Bot. Pol. 67 (1): 95-103.

CRISTOFOR S., VADINEANU A., SARBU A., POSTOLACHE C., DOBRE R., ADAMESCU M. 2003. Long-term changes of submerged macrophytes in the Lower Danube Wetland System. Hydrobiologia 506-509: 625-634.

DODDS W.K., JONES J.R., WELCH E.B. 1998. Suggested classification of stream trophic state: distribution of temperate stream types by chlorophyll, total nitrogen, and phosphorus. Wat. Res. 32 (5): 1455-1462

EGGERS C.J., KOPASKA J.A. DOWNING J.A. 2004. A century of change in macrophyte abundance and composition in response to agricultural eutrophication. Hydrobiologia 524: 145-156.

ELLENBERG H. 1974. Zeigerwerte der Gefässpflanzen Mittleuropas. Scripta Geobot. 9: 1-97.

FABISZEWSKI J., KWIATKOWSKI P. 2002. Threatened vascular plants of the Sudeten Mountains. Acta Soc. Bot. Pol. 71 (4): $339-350$.
FRENCH T.D., CHAMBERS P.A. 1996. Habitat partitioning in riverine communities. Freshwater Biol. 35: 509-520.

HEEGAARD E., BIRKS H.H., GIBSON C.E., SMITH S.J. WOLFE-MURPHY S. 2001. Species-environment relationships of aquatic macrophytes in Northern Ireland. Aquatic Bot. 70: $175-223$.

JURKO A. 1986. Plant communities and some questions of their taxonomical diversity. Ekologia 5 (1): 3-32.

KAPLAN Z., PROCHÁZKA F. 2001. Potamogeton alpinus Balbis. I: Čeřovský J., Feráková V., Holub J., Maglocký Š., Procházka F. (eds) Červená kniha ohrožených a vzácných druhů rostlin a živočichů ČR a SR. Vol. 5. Vyšší rostliny, p. 291, Príroda a.s., Bratislava.

KĄCKI Z., DAJDOK Z., SZCZĘŚSIAK E. 2003. Czerwona lista roślin naczyniowych Dolnego Śląska. In: Z. Kącki (ed.) Zagrożone gatunki flory naczyniowej Dolnego Śląska. Inst. Biol. Roślin UWr., PTPP proNatura, Wrocław. (in Polish)

KHEDR A.H.A., EL-DEMERDASH M.A. 1997. Distribution of aquatic plants in relation to environmental factors in the Nile Delta. Aquatic Bot. 56: 75-86.

KOZAK M., NOWAK A., OLSZANOWSKA-KUŃKA K. 2005. Materials to the distribution of threatened vascular plants in the Opole Silesia. Nat. J. 38: 45-86.

KRASKA M., PIOTROWICZ R., KUJAWA-PAWLACZYK J. 2004. Habitat and growth conditions of the rare Potamogeton hybrids: $P . \times$ sparganifolius Least. ex Fr. and $P . \times$ nericius Hagstr. in the Drawieński National Park. Acta Soc. Bot. Pol. 73 (1): 47-51.

KURIMO U. 1979. Effects of pollution on the aquatic macroflora of the Varkaus area, Finnish Lake District. Ann. Bot. Fennici 7: 213-254.

LAURIDSEN T.L., SANDSTEN H., MOLLER P.H. 2003. The restoration of a shallow lake by introducing Potamogeton spp.: The impact of waterfowl grazing. Lakes \& Reservoirs: Res. Management 8: 177-187.

MATUSZKIEWICZ W. 2001. Przewodnik do oznaczania zbiorowisk roślinnych Polski. Vademecum Geobotanicum 3. PWN, Warszawa, 537 pp. (in Polish)

MESTERS C.M.L. 1995. Shift in macrophyte species composition as a result of eutrophication and pollution in Danish transboundary streams over the past decades. J. Aquatic Ecosys. Health 4: 295-305.

MIREK Z., PIĘKOŚ-MIRKOWA H., ZAJĄC A., ZAJĄC M. 2002. Flowering Plants and pteridophytes of Poland a checklist. Krytyczna lista roślin naczyniowych Polski. Biodiversity of Poland 1. Różnorodność biologiczna Polski 1. W. Szafer Institute of Botany, Polish Academy of Science. Instytut Botaniki im. W. Szafera. 303 pp.

NOWAK A., NOWAK S. 2004. Potamogeton praelongus Wulfen and its occurrence in the Opole Silesia (SW Poland). Časopis Slezskeho Zemskeho Muzea Opava (A) 53: 279-282.

NOWAK A., NOWAK S., SPAŁEK K. 2003. Red list of vascular plants of Opole Province. Nature J. 36: 5-20.

PARINET B., LHOTE A., LEGUBE B. 2004. Principal component analysis: an appropriate tool for water quality evaluation and management - application to a tropical lake system. Ecological Modelling 178: 295-311.

PODBIELKOWSKI Z. 1967. Zarastanie rowów melioracyjnych na torfowiskach okolic Warszawy. Monogr. Bot. 23 (19): 1-170. (in Polish)

POTT R. 1995. Die Pflanzengesellschaften Deutschlands. 2 Aufl. Verl. E. Ulmer, Stuttgart.

PRESTON C.D. 1995. Pondweeds of Great Britain and Ireland. Handbook No. 8. Botanical Society of the British Isles, London.

PRESTON C.D., CROFT J.M. 1997. Aquatic plants in Britain and Ireland. Harley Books, Colchester, Essex, 209 pp.

PROCHÁZKA F. (ed.). 2001. Černý a červený seznam cévnatých rostlin České republiky (stav v roce 2000). Příroda, Praha, 18: 1-166. (in Czech) 
PROCHÁZKA F., RYDLO J. 2001. Potamogeton praelongus Wulfen. In: Čeřovský J., Feráková V., Holub J., Maglocký Š., Procházka F. (eds), Červená kniha ohrožených a vzácných druhů rostlin a živočichů ČR a SR. Vol. 5. Vyšší rostliny, p. 293, Príroda a.s., Bratislava. (in Slovak)

PROCHÁZKA F., HUSÁK Š. 2001. Potamogeton friesii Rupr. In: Čeřovský J., Feráková V., Holub J., Maglocký Š., Procházka F. (eds), Červená kniha ohrožených a vzácných druhů rostlin a živočichů ČR a SR. Vol. 5. Vyšší rostliny, p. 292, Príroda a.s., Bratislava. (in Slovak)

RENNWALD E. (ed.) 2000. Verzeichnis und Rote Liste der Pflanzengesellschaften Deutschlands. Bundesamt für Naturschutz, Bonn-Bad Godesberg.

RIIS T., SAND-JENSEN K. 2001. Historical changes in species composition and richness accompanying perturbation and eutrophication of Danish lowland streams over past 100 years. Freshwater Biol. 46: 269-280.

RIIS T., SAND-JENSEN K., VESTERGAARD O. 2000. Plant communities in lowland Danish streams: species composition and environmental factors. Aquatic Bot.: 255-272.

RINTANEN T. 1996. Changes in the flora and vegetation of 113 Finnish lakes during 40 years. Ann. Bot. Fenn. 33: 101-122.

RODWELL J.S. (ed.). 2000. British plant communities 4. Aquatic communities, swaps and tall-herb fens. Cambridge University Press. 283 pp.

SAND-JENSEN K., RIIS T., VESTERGAARD O., LARSEN S.E. 2000. Macrophyte decline in Danish lakes and streams over the past 100 years. J. Ecol. 88: 1030-1040.

SCHUBE T. 1903. Die Verbreitung der Gefässpflanzen in Schlesien, preussischen und österreichischen Anteils, 361 pp., Druck von R. Nischowsky, Breslau.

SCHUBE T. 1905. Ergebnisse der Durchforschung der schlesischen Gefässpflanzenwelt im Jahre 1904. Jahr.-Ber. Schles. Gesell. vaterl. Cultur 82: 41-64.

SCHUBE T. 1906. Ergebnisse der Durchforschung der schlesischen Gefässpflanzenwelt im Jahre 1905. Jahr.-Ber. Schles. Gesell. vaterl. Cultur 83: 75-95.

SCHUBE T. 1930. Ergebnisse der Durchforschung der schlesischen Gefässpflanzenwelt im Jahre 1929. Jahr.-Ber. Schles. Gesell. vaterl. Cultur 102: 72-81.
SCHUBERT R., HILBIG W., KLOTZ S. 1995. Bestimmungsbuch der Pflanzengesellschaften Mittel- und Nordostdeutschlands. G. Fischer, Jena-Stuttgart.

SENDEK A. 1976. Zmiany w rozmieszczeniu gatunków Potamogeton L. na tle antropogenicznych przeobrażeń środowiska w Górnośląskim Okręgu Przemysłowym. Phytocoenosis 5.3/4: 329-338. (in Polish)

SHANNON C.E., WIENER W. 1963. The mathematical theory of communication. Urbana, Univ. of Illinois Press, pp. 144.

SNEATH P.H.A., SOKAL R.R. 1973. Numerical taxnomy. The principles and practice of numerical classification. Freeman a. Comp., San Francisco, pp. XV+573.

SOLIŃSKA-GÓRNICKA, SYMONIDES E. 2001. Long-term changes in the flora and vegetation of Lake Mikołajskie (Poland) as a result of its eutrophication. Acta Soc. Bot. Pol. 70 (4): 323-334.

TAYLOR B.R., HELWIG J. 1995. Submerged macrophytes in a cooling pond in Alberta, Canada. Aquatic Bot. 51: 243-257.

TOMA C. 2002. Ontogenesis of the Potamogeton flower and fruitlet in SEM research. Acta Soc. Bot. Pol. 71 (2): 93-100.

TOMASZEWICZ H. 1979. Roślinność wodna i szuwarowa Polski. Rozprawy Uniwersytetu Warszawskiego, Warszawa, p. 325. (in Polish)

WIEGLEB G, TODESKINO D. 1983. Habitat conditions of Potamogeton alpinus Balbis stands and relations to the plants characters. Proceedings International Symposium on Aquatic Macrophytes, Nijmegen, pp. 311-316.

VAHLE H.-C., PREISING E. 1990. Potametea Tx. et Prsg. 42. In: Preising E. et al. 1990. The Pflanzengesellschaften Niedersachsens. Naturschutz und Landschaftspf. Nieders. 20 (7): 101-128.

VANDERPOORTEN A., KLEIN J.-P. 1999. A comparative study of the hydrophyte flora from the Alpine Rhine to the Middle Rhine. Application to the conservation of the Upper Rhine aquatic ecosystems. Biol. Conservation 87: 163-172.

ZAJĄC A. 1978. Założenia metodyczne „Atlasu rozmieszczenia roślin naczyniowych w Polsce". Wiad. Bot. 22 (3): 145-155. (in Polish) 